\title{
WOMEN'S RIGHTS IN IRAN WITH A LOOK AT THE CURRENT SITUATION OF WOMEN'S HEALTH RIGHTS IN THIS COUNTRY
}

\author{
MOJDEH Pouryazdankhah - Phd student of the Department of International \\ and European Law, V. Karazin Kharkiv National University
}

https://orcid.org/0000-0001-9192-4812

УДК 341.215.4

DOI 10.32782/LAW.UA.2021.2.4

\begin{abstract}
Главная часть. Эта публикация исследует участие Ирана в договорах по правам человека. Гендерное неравенство, принятие мер по улучшению гендерного равенства в сфере здравоохранения и Статус прав женщин на здоровъе в соответствии с иранским законодательством, а также выражение всех гендерной дискриминации, лишений и неравенства.
\end{abstract}

Въгод. Патриархат в Иране переживает кризис из-за повыпения образовательнъхх достижений женщин, изменений в структуре семьи и распространения живой феминистской прессъ. Политико-юридическая структура препятствует надлежащему рассмотрению и решению этих вопросов. патриархальнъе и эгалитарнъие гендернъие отношения - будь то дома или в обществе в изелом - не могут возникнуть до тех пор, пока женщинъ не достигнут экономической независимости. Защитники прав женщин согласнъ с тем, что в Исламской Республике Иран необходимо коренным образом пересмотреть семейное законодательство. Также необходима последовательность в подходе Ирана к своим международнъм обязательствам; и приведение своего законодательства в соответствие с международнъими стандартами и нормами, закрепленнъмми в международнъх документах по правам человека.

Ключевъе слова: права женщин, права женшин на здоровъе, договор о правах человека, гендерное неравенство, гендерная дискриминачия.
Introduction: Emphasizing the voluntary membership of governments in international law on women's health developments, this article examines women's health status and existing laws to improve the situation in Iran by looking at countries that do so under their domestic laws.

Introduction:(The relevance of research)

The first condition for having a healthy and dynamic society and health is the stability and strengthening of the family, and women guarantee the health and strengthening of the family. The family is the foundation and cornerstone of a social institution, and considering that educating the next generation is the responsibility of women. Dynamic is the result of the existence of healthy and aware women Which shows the importance of having health rights for women. Unfortunately, despite the international, international, regional organizations and groups active in the field of women's rights, we still see discrimination and lack of access to women's rights today, and it seems that this lack of access is due to ignorance and recognition of these rights by Women and the lack of government support in practice to facilitate women's access to health.

Analysis of recent research and publications, which initiated the solution of this problem and on which the author relies:

Many scientificpublications have paid great attention to the definition of the concept of "women's rights", gender equality, the effectiveness of mechanisms for the protection of human rights in general and women in 


\section{Теорія, історія держави і права, конституційне право}

particular. This scientific publication is based on the analysis of subsequent published works: "Issues in women's health and rights" January, Professor Emeritus of Obstetrics and Gynecology Assiut University Egypt; Women's Health and Human Rights, The Promotion and Protection of Women's Health through International Human Rights law 1994,Rebecca.Cook; Associate Professor (Research) and Director, International Human Rights Programme Faculty of Law, University of Toronto Toronto, Canada; Gender equality,work and health:A review of the Evidence Karen Messing, PhD,CINBIOSE, Université du Québec, Montréal, Canada and Piroska Östlin, PhD; KarolinskaInstitute, Stockholm, Sweden; Unequal, Unfair, Ineffective and Inefficient Gender Inequity in Health: Why it exists and how we can change it, Gita Sen, Piroska Östlin, Asha George, Anna Myagkykh is a Candidate of Law, Associate Professor, Coach, Human Rights Defender, Chairman of the NGO "Gender Club Dnipro" and head of the Gender Center of the State Higher Educational Institution "National Mining University" (Dnipro). Associate Professor of the Department of General Legal Disciplines of Dnipropetrovsk State University of Internal Affairs and Regional Coordinator of the Association of Women Lawyers "YurFem", Olena Uvarova, Associate Professor of Theory and Philosophy of Law, Ms. Olena Uvarova, Associate Professor of the Department of Theory of State and Law, Leading Specialist of the International Relations Department, Coordinator of Satellite Events of the Forum, Yaroslav the Wise National University of Law, Former National Adviser to the Council of Europe and Member of the Committee for the Protection of Women in Ukraine,Some aspects of women's right to health, including older women, to the works of Ukrainian writers in particular: Syroid T.,Fomina L., Havrylenko O.»

Purpose of this article: This article examines the strengths and weaknesses of the current domestic law of Iran in the field of ensuring the mental and physical health of women in society. And intends a logical solution to get out of this situation, which is to make a fundamental change in the structure of domestic law and join international agreements and treaties on women's rights. And check the health of women.

\section{Presenting the issue:}

Iran has an ancient culture and antiquity. In the history of the ancient civilizations of the world, this country has had the most prominent and important contribution in giving life and brilliance to other peoples of the world. The view of Iranians towards women has been positive and significant in most periods, especially in ancient times when they considered her a sacred, pure creature and respected her status. [1,page 17]

Undoubtedly, the social status of women in any period and history is not separate from the general status of that society. Because one of the oldest human civilizations is the Ilam civilization in the west of the Iranian plateau, The statue of the Queen of Ilam represents the social status of women at that time. After the establishment of the Medes in western Iran, the imperial mother regime gradually gave way to the patriarchal regime. However, agricultural activity was with women; And men paid special attention to women. After the Medes, it is the turn of the Achaemenid dynasty and the Persians, whose founder is Cyrus the Great. The woman became the head of the tribe as well as the judge; There were still remnants of the imperial mother system. In Achaemenid rule, men and women had equal rights. In Median society, The woman's social status and rights in the family remained protected; In the religion of Zoroaster, neither man nor woman is superior to each other, and the two are equal in terms of creation. During this period, which is one of the brilliant periods of motherhood in Iran, Zoroastrian woman had the highest transcendent rights in the first century of the emergence of Zoroastrianism and also during the Achaemenid period, and is going through one of the most brilliant historical periods. After the defeat of the Achaemenids, the social status of the Iranian woman changed and went downhill. Therefore, it also affected the situation and destiny of Iranian women. During the Parthian period, although the position of the Iranian woman was somewhat strengthened; However, the Seljuk rule and its effects and the 
influence of Hellenism had their effect. During the Sassanids, when the religion of Zoroaster regained its original importance and the system of government was governed by a royal cleric; An Iranian woman under the teachings of the Zoroastrian religion again gained rights and privileges. The Sassanid era not only in terms of Iranian history; It is important for the whole world. According to Avestan laws:

1) The woman had the right of ownership and could manage her property independently.

2) A woman could be the guardian or custodian of her children.

3) the wife could have been tried by her husband in accordance with the law; And manage affairs in her name (in case of husband's illness)

4) The woman could complain to the prosecutor about her abusive and abusive husband and ask for his punishment.

5) The husband has no right to marry his daughter without her wife's permission.

6) A woman's testimony was accepted in court.

7) The woman could have been an arbitrator or a lawyer.

8) A woman could be a testator and bequeath all her property.[2]

Prior to Islam, the status of women in Iran was almost equal between men and women, and the status of women was highly respected and valued. The peak of power was related to the Achaemenid period. After the advent of Islam, due to the influence of tribal traditions and ethnic prejudices, social conditions and women's rights declined, and only during the Mongol dynasty was it a little exceptional in terms of freedom and status. But during the Safavid period, Iranian men kept their women under restrictions, which reached their peak during the Qajar period, Boys between the ages of 1014 could only enter into a temporary marriage contract (only to meet sexual needs) until they reach puberty. In general, the emergence of the women's movement in Iran dates back to the 19th century, when Iran experienced major economic and social events, and in the middle of the Constitutional Revolution, Iranian society experienced an organized effort by women to change their social conditions. Europe's contact with the Iranian people and their attention to the repressive conditions of Iranian women forced them to make changes in relation to the problems. Among the most important factors contributing to the development of women's organizations and the increase in their activities, in addition to the devotion of the early Iranian "feminists," are

a) the emergence and spread of the Baha'i religion, which emphasized women's freedom,

b) the influence of Western liberal thought on Iranian intellectuals,

c) the existence of Europeans in and their increased contact with Iran both before and after the First World War,

d) the Russian Revolution of 1917 and its influence on some Iranian intellectuals,

(e) the emergence of the women's movement in neighboring Turkey and Egypt, and finally

f) the American and British women's victories in achieving the right to vote in the late 1910's. [3, P 36-38]

Important events took place in the Pahlavi dynasty, including the discovery of the hijab in 1936, women's suffrage in 1963, the passage of the Family Protection Act 1964, which repealed the Unilateral Divorce Act, and the custody of a child after divorce due to polygamy and Or after the death of the father, it was the responsibility of the mother.[4,P 25]

During the Pahlavi period, the women's rights movement entered an institutionalized, legitimate field of activity, and their activities were fully in line with government positions. In Iran, a federation of women's organizations was established, which by 1959 had fourteen affiliated organizations and gradually became the Supreme Council of Women, And then the Iranian Women's Organization, the organization remained until 1978. [5,P432]

But after the Iranian revolution, which is the main topic of the article, to what extent is the achievement of women's rights, which ensure women's mental and physical health, and women's health rights, and ultimately the health of society, included in the laws?

after revolution, ulama they began laying the groundwork for the establishment of an Islamic Republic. Their first move in that direction was to condition the presence of women in the public sphere by demanding observance of religious laws and new ordinances issued by 


\section{Теорія, історія держави і права, конституційне право}

the clerics. Ayatollah Khomeini demanded the abolition of the Family Protection Act, ordered the implementation Sharia laws in the country, and issued a decree demanding women dress "properly." Numerous boundaries separating men and women in society were erected: "males and females were separated in higher education classes, women were banned from some professions, and female students were barred from certain disciplines in the universities , A decree dismissed all women judges and barred female students from law schools, Women were forbidden to participate in some sports and not allowed to watch men in sports fields. The new Sharia laws gave men an absolute right to divorce their wives without having to produce any justification. Child custody laws were also changed in favor of men: after divorce, women are entitled to keep their boys only up to the age of two and girls until seven. After these ages, fathers have the right to full custody. Women's judgment as evidence in court was declared to be worth half a man's. Blood money for a murdered woman was set to be half that of a man. Female marriage age was reduced to 13 and professional secular women were encouraged to retire from their public occupations in order to support male employment. In the first decade of the revolution, the state continued to take away the rights women had previously achieved. In the second decade, Iranian women went on the offensive and began to put tremendous pressure on the state to retreat. prevailing gender segregation, unequal division of labor, widespread domestic violence, and the organizational and exploitative biases within the Iranian Islamic family. [6,P 438-445]

After the Islamic Revolution, the status of women was completely ignored for five years, the hijab was strongly encouraged, These changes are very important and reflect the deprivation of women's freedom in the new laws. It is the duty of a woman as a husband both in the imperial system and after the revolution to have marital sex and to give birth to and raise children. While a married man in both pre- and post-revolutionary systems could, under certain conditions, enter into any number of temporary marriages in addition to permanent marriages, under no circumstances could a married woman marry more than one man. Under both systems, the husband is the head of the household, and the wife's duty was obedience under the Family Protection Act of 1975 as well as Sharia, and only the Family Protection Act of 1975 made less legal distinction between the sexes. (Education was compulsory for girls and women and girls were legally entitled to equal education as well as equal rights to work). And women in the Islamic Republic still have the right to study, but only in unisex institutions. They are not barred from working outside the home, but dismissals, early retirement plans, reductions in several day care programs and pregnancy benefits, and an emphasis on the role of mothers pushing wage-earning women to leave their jobs.[7,P 477-484]

Laws related to the protection of women in Iranian law: A) The tenth principle of the constitution : Since the family is the fundamental unit of the Islamic society, all relevant laws, regulations and plans should be based on Islamic law and ethics in order to facilitate the formation of the family, protect its sanctity and strengthen family relations.and the twenty-first principle of the constitution of the Islamic Republic: The government is obliged to guarantee women's rights in all respects in accordance with Islamic norms and to do the following:

1- Creating favorable conditions for the growth of a woman's personality and the restoration of her material and spiritual rights.

2- Supporting mothers, especially during pregnancy and child custody, and supporting orphaned children.

3- Establishing a competent court to preserve the integrity and survival of the family.

4- Creating special insurance for widows and elderly and homeless women.

5- Granting custody of children to worthy mothers in order to envy them in the absence of a religious guardian .[8]

B) Subject laws: 1) The law and executive regulations for the provision of orphaned women and children.( Law on Providing Orphaned Women and Children

1374.05.11 - .26549 T $14549 \mathrm{H}$ - 1374.05.17 - 455\& Higher education - Education - Banking and Monetary - Budget - Social Security - 
Support Family - Work - Criminal - Housing - Institutions of the Islamic Revolution \& Country Welfare Organization Cabinet in the meeting dated 1374.5.11 according to proposal number 856.3532 dated 1373.11.25 Welfare Organization of the country and according to Articles (5) and (9) of the Law on Women and Unaccompanied Children - Approved in 1992 )

2) The law requiring tetanus vaccination for premarital women .(approved 12,04,1988)

3) Prohibition of night work for women. (Approved 20,11,1990)

4) Prohibition of referring hard and harmful work to women (Labor Law, Article 75 , approved 20,11,1990)

5) Prohibition of work. For pregnant women from 6 weeks before delivery to 4 weeks after (Labor Law, approved 20,11,1990)

6) Policies and strategies to promote women's health Approved for the six hundred and thirteenth session dated 08/08/2007 of the Supreme Council of the Cultural Revolution. [9]

Iran's membership in international organizations and cooperation with them:

- The accession of the Government of Iran to the International Treaty of Paris and Geneva on the Prevention of Criminal Behavior towards Women .5,January 1932.

- The Law of Accession of the Government of Iran to the International Convention on the Prevention of Transactions and Seduction of Large Women, 10, January,1935.

- Iran became a member of the United Nations in 1946.

- Member of the UN Commission on the Status of Women, which is the highest supervisory authority on women in the United Nations and Iran was elected as a full member of the commission, Iran has been elected to the UN Commission on the Status of Women for the second time in two decades; Iran first became a member of the Commission on the Status of Women in 2010; A commission with representatives from 45 countries that has an advisory and oversight role in promoting gender equality and women's empowerment, and its recommendations have no executive guarantee. According to the agreement reached at the 61 st meeting of the Commission on the Status of Women, the Commission's priority next year is to achieve gender equality and empowerment of all women and girls in the context of climate change and to implement policies and programs to reduce the risks of environmental change and natural disasters. Is. Also, the subject of this commission in 2022 will be the economic empowerment of women in the working market.[10]

- Membership in World Health Organization 1948 and the law amending the articles of the World Health Statute 1972 and Amendment of the Statute of the World Health Organization 2009.

- Law on Accession to International Category 111 on Discrimination in Employment.

- Iran's accession to the International Convention against Discrimination in Education .

- The law related to the International Convention on the Elimination of All Forms of Racial Discrimination .

- The Law on Accession to International Convention No. 100 concerning equal pay for male and female workers for equal work .[11]

The Convention on the Elimination of All Forms of Discrimination against Women is an international instrument ratified by the United Nations General Assembly in 1979, to which almost all countries are members. The Islamic Republic of Iran is one of the few countries in the world that has not acceded to this convention and the reason is the conflict between the articles of the convention and the laws of the Islamic Republic of Iran. The most important of these conflicts are:

Inheritance: According to Islamic rules, the share of women's inheritance is half the share of men.

Diyat: The diyat of women is half that of men.

The right to divorce: The right to divorce is absolutely with men.

The right of women to travel: Women without the direct permission of their husbands or male guardians (the only criterion for their selection as guardians is their physical masculinity). Traveling in this sense means even stepping out of the house.

The testimony of women in the courts and formal courts, the testimony of women is as valuable and credible as half of men. That is, 


\section{Теорія, історія держави і права, конституційне право}

the testimony of two women is equivalent to the testimony of a man in court.

Women cannot be judges. The judge (ruler of Sharia) is chosen only from among men. Recently, in some places (such as family courts), women have been ostensibly employed as judges, but their rulings or decisions without the approval of a sharia judge are worthless.

Custody of children: Guardianship or custody of children is always with men.

Minority Women: Women who are members of religious minorities (especially those belonging to minorities who are not called "People of the Book") suffer from "double discrimination." Because they are both women and minority groups.

Marriage: Men can have four wives and of course women can not have more than one husband at the same time.

Temporary marriage - Men can have concubines. This is a Shiite rule and the Sunnis do not accept it.

Women who marry foreigners lose their citizenship according to the Islamic rules of Iran.

People who leave the religion of Islam (commit apostasy), if they are men, are immediately sentenced to death, but in the case of women, the ruling is to keep them in prison and whip them every day during the daily prayers until To renounce apostasy and return to Islam. This "privilege" is given to women for believing that women are weak-minded, and unlike men whose decisions are decisive, women's decisions are due to mental weakness.

Clothing: In the Islamic rules governing Iran, Hijab for women is mandatory.[12]

An important but necessary issue is the accession of the government of the Islamic Republic to the conditions. And what is important is the possibility of imposing a condition on the substantive provisions of the Convention on the Elimination of All Forms of Discrimination. The Convention also implicitly prescribes such a condition, as interpreted in Article 28.It is stated that this convention is generally conditional, but as mentioned earlier, the rule. The general emphasis is on the non-contradiction of the condition with the subject and purpose of the Convention. With reference to the Convention, it can be inferred that in order to fulfill the central slogan of the Convention, ie "full equality between men and women in order to ensure women's participation on an equal footing with men in the political, social, economic and social life of the country." To complete the capabilities and talents of women in the service of the country and humanity, two things are necessary: one is "changing the traditional role of men and women in society and the family" and the other is "taking the necessary measures to eliminate discrimination in all its forms." Hence, even if there are some distinctions and inequalities that are not discriminated against on the basis of traditional beliefs on any historical, cultural, social, or religious basis, they must be eliminated. In the case of the Convention on the Elimination of All Forms of Discrimination against Women, it does not appear that the problem will be resolved through accession with the general condition, because the general condition of "non-contradiction with the holy law of Islam" in the bill of accession And indefiniteness, inconsistency with the subject matter and purpose of the Convention, and, consequently, violation of Article 282 , violation of the general principles of treaty law, including the impossibility of invoking domestic law in discharging responsibility for the implementation of the treaty, and finally incompatibility with ratification without The terms of the human rights treaties have been challenged by some other member states of the Convention and have prompted reactions and pressures from the Committee on the Elimination of All Forms of Discrimination against Women and other human rights bodies in the United Nations.[13,P 59-60,72,74,107]

Women's participation in Iran has had very good results in benefiting from the health situation compared to the past and the first decades of the revolution. Iran has gained many health achievements in the past decades and the life expectancy at birth has increased to more than 75 year for both sexes, NCDs including mental disorder and traffic injury are still among the highest rank for cause of death and morbidity. In 2014, the Ministry of Health and Medical Education (MOH\&ME) responded to challenges arising from epidemiological transition and changes 
in demography, social determinants of health, high out-of-pocket health expenditure and numerous uninsured people, by launching the Health Transformation Plan (HTP), The HTP was recently evaluated by WHO in late 2016, which substantiated many achievements that includes insuring additional 9 million population, as well as, identified options for existing challenges for progress towards UHC. A comprehensive program of urban health care delivery based on Family Practice [FP] approach is being piloted in several provinces, as part of the HTP, especially in the fringes of big cities. [14]

Despite the promising trend of women's health in Iran over the past three decades, there is still a difference between women and men with respect to mental, physical, and social health. Mental disorders and domestic violence are other high priority problems among Iranian women. social determinants of health have a remarkable relationship with violence not only in Iran, but also on a global scale. According to the reports of international organizations, Iranian women's health indicators on average are one of the best in the Eastern Mediterranean region. the challenges to women's health in Iran are rooted in two main areas. The first comprise the social determinants of health which entitle women to equal social positions with men regardless of socio-cultural classification. Women's social values and rights vary in different cultures and locations. For instance, in very traditional societies like some ethnicities in Iran, the social rights of men and women are not equal. The second area refers to the health system and its response to women's needs. Comprehensiveness of a health system is a very important factor for an effective response to the needs of the target population. In this regard, there are two main defects in Iran's health system. Although mental disorders, breast cancer, and violence are placed at the top of the burden of diseases' list among Iranian women, these priorities have not been seen in the current basic service packages at different levels of Iran's health system. In addition, the imperfect referral system along with fragmentation between different parts of the health system results in a lack of continuity of care, which, in turn, provokes incomplete results for healthcare.[15,P 2,3,7]

Despite the impressive success in health care promotion in the Iranian health care system, Iranian women are still in need of receiving sexual health care and appropriate HIV/AIDS services, There is a lack of studies on the SRH needs of Iranian women.[16,P 637]

Second, women's employment status has changed dramatically.

Third, women's suffrage for equal opportunities, both in government and in industry, is different than before.

Fourth, the achievements of women in the field of education. all women's health care have improved over the course of time and the reason for this is the increased level of community development. But, Iran's programs for supporting women do not cover the entire target population. In recent years, the number of women in need of financial support has increased. The economic crisis of the country caused by international economic sanctions, years of war, and inappropriate resource management of the government has had a severe effect on the welfare of Iranians It increased inflation and unemployment and decreased the financial accessibility of health services. The review of health laws and policies of Iran indicates that Iran's Constitution recognizes the right to health as a fundamental human right of everyone. To realize the right to health, there should not be anyone deprived from the enjoyment of this right.In the laws of Iran, men are regarded as the breadwinners of the family, and women are considered to be in need of a male guardian to provide the necessities of life for them . [17,P 7]

According to the report of the World Economic Forum in 2020, In terms of health and survival,Iran is ranked 130th and politically ranked 145th out of 153 countries. [18]

\section{Conclusion}

Women's health includes emotional, social, cultural, spiritual and physical welfare and it is not only absence of disease and disability. women's health is more vulnerable than men for different reasons and in addition to the biological properties it is affected by cultural, social, economic and political determinant factors. Women's access to education, health 


\section{Теорія, історія держави і права, конституційне право}

care, health information and services needed are not in the same status as men and wherever this difference is greater, the situation of children and their families is worse and their families are more deprived. Women's health is related to their life cycle issues and not just reproductive things. So women's health improving requires a holistic, coherent and systematic approach, the relationship between health, economic and social departments and policy is necessary to achieve the goals of women's health in the society.[19]

Gender parity in pay is proving hard to achieve. No country (including the top-ranked ones) have yet achieved gender parity in wages. [20]

In Iran, discrimination based on gender in enjoyment of the right to health is prohibited. Making health services physically and financially accessible to the entire population and removing social and cultural barriers of women's access to health services are main considerations of the health laws and policies of Iran. But there are disparities in health status and access of women to health services around the country. Some groups of women, including the poor, the elderly, the disabled, the illegal immigrant, and those without an appropriate male guardian, and rural women have limited access to health services in Iran. To realize women's right to health, this country should immediately remove the disparities and use all the necessary means including legislative, administrative, budgetary, promotional, and judicial measures. National plans on women's empowerment and support should be interpreted in provincial programs and action plans. Moreover, a monitoring system and certain benchmarks for tracing the progress of the plans should be established. Realizing other economic, social, and cultural rights including the rights to food, shelter, education, work, social security, and participation in society will improve the Iranian women's enjoyment of their right. The review of health laws and policies of Iran indicates that almost all the obligations defined in international human rights treaties for protection of women's right to health are covered by national laws. Iran's Constitution recognizes the right to health as a fundamental human right of everyone. To realize the right to health, there should not be anyone deprived from the enjoyment of this right. All the vulnerable groups of women who cannot afford healthcare and are not covered by current support programs should be identified and supported. Disparities in the health status of women belonging to different socioeconomic groups of population and their access to healthcare should be removed. Iran should take steps immediately to improve the health and living situation of inhabitants of remote and rural areas by providing enough healthcare facilities and urban infrastructure such as appropriate sanitation and safe water. Particularly, Iran should increase access to midwives and gynaecologists in these areas. Empowering women by providing more opportunities for them to work will help them to become independent and have more control over their lives and health. Besides, enhancing the knowledge of society and women themselves about women's rights will be helpful in the removing discrimination and violence against women. Nevertheless, effective deterrent judicial means for the protection of women against violence are necessary. The law that requires the consent of the husband to access health services is in contrast with the wife's rights to autonomy and control of her body and health, and should be amended. Also, at the level of health services, more attention should be paid to the mental and sexual and reproductive health of women and prevention of NCDs. The health of girls is very important from individual and public health points of view. Child marriage should be prohibited in Iran, and children should receive age $\square$ appropriate education about sexual and reproductive health. An increase in the number of divorced girls in Iran necessitates special attention of the government to the empowerment of these children and providing them with social security measures and support. Since child marriage often happens among low socioeconomic groups of society, the government's ignorance of the economic and social rights of these children will endanger their future lives. Finally, the right to health is a right to underlying determinants of health too. Therefore, homeless women should be provided with a shelter; malnourished women should receive nutritious food, and 
poor women should be given social security means. Everyone, according to the Iran's Constitution and international human rights laws, should be provided with an adequate standard of living. Finally, defining the rights in the constitution or legislation is not enough for protection of rights; they should be translated into reality. Iran should use all the necessary means including legislative, administrative, budgetary, and judicial measures towards the full realization of women's right to health. National plans on women's empowerment and support should be interpreted in provincial programs and action plans. They should include detailed lists of related authorities and their responsibilities. Moreover, a monitoring system and certain national benchmarks for tracing the progress of these plans should be established in Iran. Appropriate deterrent laws and sanctions should be defined for every third party, including men who violate the rights of women to access healthcare. Society has the potential to help the government to identify women suffering violation of their rights. The government should facilitate this collaboration and prepare needed facilities.[21]

\section{Reference}

1.Nazari Sareh, The days of women in Iranian dynasties, Shabak journal,2014 ,Page 17-28, Volume 2, Number 3, Volume 1 Humanities Studies, Al-Zahra Faculty of Social and Economic Sciences, URL: www.sid.ir/ FileServer/JF/100038139510E03.pdf.

2.Ahangar Kaveh ,The social status of women in ancient Iran, A passage through history ,18/July's/2013, URL: tamadonema.ir.

3. Sansarian The Women's Rights Movement in Iran Mutiny, Appeasement, and Repression From 1900 to Khomeini, 1982, page 36-38.

4. 1.Nazari Sareh, The days of women in Iranian dynasties, Shabak journal,2014 ,Page 17-28, Volume 2, Number 3, Volume 1 Humanities Studies, Al-Zahra Faculty of Social and Economic Sciences, URL: www.sid.ir/ FileServer/JF/100038139510E03.pdf

5. Ali Akbar Mahdi ,The Iranian Women's Movement: A Century Long Struggle, volume 94, October , 2004, Page. 432 , URL: www. researchgate.net/publication/228021795.

6. Ali Akbar Mahdi ,The Iranian Women's
Movement: A Century Long Struggle ,volume 94, October , 2004 , Pages 438-445, pdf. URL: www.researchgate.net/publication/228021795.

7. Patricia J. Higgins, Women in the Islamic Republic of Iran: Legal, Social, and Ideological Changes, Vol. 10, No. 3 (Spring, 1985), pp. 477494 (18 pages).

8. Article 10 of the Constitution, Text of the Constitution of the Islamic Republic of Iran 3,Dec, 1979.

9. Research Center of the Islamic Consultative Assembly, Policies and Strategies for Promoting Women's Health . URL: rc.majlis.ir/fa/law/show/128260.

10. Euronews, 22/04/2021, Election of Iran to the membership of the Commission on the Status of Women; UNHCR: It was a dark day for human rights. URL:www.google.com/ amp/s/per.euronews.com/amp/2021/04/22/unelects-iran-commission-women-rights.

11.1) Approved law 21/5/1948. https:// rc.majlis.ir/fa/law/show/94089.

2) Approved law 7/5/1964 . https://rc.majlis. ir/fa/law/show/95510.

3) Approved law 26/2/1968 . https:// rc.majlis.ir/fa/law/show/96175.

4) Approved law 21/7/1968 . https:// rc.majlis.ir/fa/law/show/96244.

5) Approved law 8/5/1972. https://rc.majlis. ir/fa/law/show/96175.

12.Aghaei Diba, Bahman, Cases of conflict between the International Convention on the Elimination of All Forms of Discrimination against Women and Iranian law,3,Sep,2017, URL:www.radiofarda.com/amp/womendiscrimination-laws-iran/28715982.html.

13. Mustafa Fazaeli, Convention on the Elimination of All Forms of Discrimination against Women and, General conditions entered on it, Legal Journal, Journal of the Center for International Legal Affairs, Vice President for Legal Affairs and Parliamentary Affairs

No. 34,Page 57-110, 2006. URL: www. cilamag.ir/article_17855_1121573b149e0fe127 697e3454f1bad0.pdf.

14.World Health Organization, country cooperation strategy,Islamic republic of Iran. May,2017.URL:apps.who.int/iris/bitstream/ handle/10665/136898/ccsbrief?sequence.

15.Hassan Joulaei, Najmeh Maharlouei, 


\section{Теорія, історія держави і права, конституційне право}

,Kamran Bagheri lankarani, ,Alireza Razzaghi \& Maryam Akbari, Narrative review of women's health in Iran: challenges and successes, 2016, International Journal for Equity in Health, Joulaei et al. International Journal for Equity in Health (2016) 15:25 DOI 10.1186/s12939016-0316-x, Article number 25.URL: https:// equityhealthj.biomedcentral.com/track/ pdf/10.1186/s12939-016-0316-x.pdf.

16. Soghra Khani, Lida MoghaddamBanaem,Eesa Mohamadi, Abu Ali Vedadhir and Ebrahim Hajizadeh , Women's sexual and reproductive health care needs assessment: an Iranian perspective, Eastern Mediterranean Health Journal,World Health Organization, EMHJ - Vol. 24 No. 7 - 2018. URL: applications.emro.who.int/emhj/v24/07/ EMHJ_2018_24_07_637_643.pdf?ua=1.

17.Hassan Joulaei, Najmeh Maharlouei, ,Kamran Bagheri lankarani, ,Alireza Razzaghi \& Maryam Akbari, Narrative review of women's health in Iran: challenges and successes, 2016, International Journal for Equity in Health, Joulaei et al. International Journal for Equity in Health (2016) 15:25 DOI 10.1186/s12939016-0316-x, Article number 25.URL: https:// equityhealthj.biomedcentral.com/track/ pdf/10.1186/s12939-016-0316-x.pdf..

18. World Economic Forum, Global Gender Gap Report 2020,URL: www3.weforum.org/ docs/WEF GGGR 2020.pdf

19. Seyed Masood Mousavi, Mahdieh Mojibian, Ehsan Zarepur, Niloofar Mohammadi Kamal Abadi, Rezvan Sadr Mohammadi, and Reza Bidaki ,Study of Women's Health Indices: A Review Study in Iran, International Journal of Collaborative Research on Internal Medicine \& Public Health .URL:internalmedicine. imedpub.com/study-of-womens-health-indices-
Main part. This publication examines participation Iran in human rights treaties. Gender inequality, taking measures to improve gender equality in health care and The status of women's health rights according to Iranian law and the expression of all gender discrimination, deprivation and inequality.

Conclusion. Patriarchy is in crisis in Iran, due to the increased educational attainments of women, changes in family structure $\mathcal{E}$ the proliferation of a lively feminist press. The political-juridical structure prevents these issues from being properly addressed and resolved. In particular, the transition from patriarchal to egalitarian gender relations-whether in the home or in the wider society-cannot occur until women have achieved economic independence. Women's rights advocates agree that there must be a major overhaul of the family laws in the Islamic Republic of Iran. Also needed is consistency in Iran's approach to its international obligations; and harmonization of its laws with international standards and norms as enshrined in the international human rights instruments.

Keywords: women's rights, women's Health rights,Human Rights treaty, Gender inequality, gender discrimination .

a-review-study-in-iran.php?aid $=17302$.

20.World Economic Forum, Global Gender Gap Report 2020 ,URL: http://www3.weforum. org/docs/WEF_GGGR_2020.pdf

21.kokabisadeghi Fatemeh, Women's right to health in Iran: Domestic implementation of international human rights law, 18,January,2019, The International Journal of Health Planning and Management, volume 34,Issue 2. URL:onlinelibrary.wiley.com/doi/ full/10.1002/hpm.2737. 